\title{
Vitamin D deficiency and low bone status in adult female garment factory workers in Bangladesh
}

\author{
Md Zahirul Islam ${ }^{1}$, Abu Ahmed Shamim ${ }^{1}$, Virpi Kemi ${ }^{1}$, Antti Nevanlinna ${ }^{2}$, Mohammad Akhtaruzzaman ${ }^{3}$, \\ Marika Laaksonen ${ }^{1}$, Atia H. Jehan ${ }^{4}$, Khurshid Jahan ${ }^{3}$, Habib Ullah Khan ${ }^{4}$ and Christel Lamberg-Allardt ${ }^{1}$ * \\ ${ }^{1}$ Calcium Research Unit, Division of Nutrition, Department of Applied Chemistry and Microbiology, University of Helsinki, \\ PO Box 27, Helsinki 00014, Finland \\ ${ }^{2}$ IT Department, University of Helsinki, PO Box 26, Helsinki, Finland \\ ${ }^{3}$ Institute of Nutrition and Food Science, University of Dhaka, Dhaka 1000, Bangladesh \\ ${ }^{4}$ Centre for Nuclear Medicine and Ultrasound, Mitford, Dhaka 1100, Bangladesh
}

(Received 3 April 2007 - Revised 8 October 2007 - Accepted 22 October 2007)

The manufacture of garments is the main industry in Bangladesh and employs 1.6 million female workers. Due to the indoor lifestyle and low dietary intake of calcium, we hypothesised that they are at risk of low vitamin D and bone mineral status. Two hundred female garment workers (aged 18-36 years) were randomly selected. Serum 25-hydroxyvitamin D (S-25OHD), serum intact parathyroid hormone (S-iPTH), serum calcium (S-Ca), serum phosphate (S-P) concentration and serum alkaline phosphatase activity (S-ALP) were measured from fasting samples. Bone indexes of hip and spine were measured by dual-energy X-ray absorptiometry. The mean S-25OHD $(36.7 \mathrm{nmol} / \mathrm{l})$ was low compared to that recommended for vitamin D sufficiency. About $16 \%$ of the subjects were found to be vitamin D-deficient (S-25OHD $<25 \mathrm{nmol} / \mathrm{l})$. We observed a high prevalence $(88.5 \%)$ of vitamin D insufficiency $(\mathrm{S}-25 \mathrm{OHD}<50 \mathrm{nmol} / \mathrm{l})$ as well as a significant inverse relationship between S-25OHD and S-iPTH $(r-0 \cdot 25, P \leq 0 \cdot 001)$. A decrease in S-25OHD $(<38 \mathrm{nmol} / 1)$ and an increase in S-iPTH $(>21 \mathrm{ng} / \mathrm{l})$ was associated with progressive reduction in bone mineral density at the femoral neck and lumbar spine. According to the WHO criteria, the mean $T$-score of the femoral neck and lumbar spine of the subjects were within osteopenic range. We observed that subjects with a bone mineral density $T$-score $<-2.5$ had a trend of lower values of BMI, waist-hip circumference, mid-upper-arm circumference, S-25OHD and higher S-iPTH and S-ALP. The high prevalence of hypovitaminosis D and low bone mineral density among these subjects are indicative of higher risk for osteomalacia or osteoporosis and fracture.

25-Hydroxyvitamin D: Bone mineral density: Vitamin D status: Female garment workers: Bangladesh

Osteoporosis is a disease in which the density of bone is decreased with a consequent increase in bone fragility and susceptibility to fracture risk. Women are four times more likely than men to develop this disease. Osteoporosis has profound implications for an individual and for the economics of society. Although the exact mechanisms that lead to osteoporosis are not fully understood, two major determinants are known: peak bone mass during childhood and adolescence, and the rate of bone loss during ageing ${ }^{(1)}$.

Indeed, some studies have related growth in infancy and childhood to the later risk of hip fractures ${ }^{(2)}$. An adequate supply of vitamin D is important to maximise bone mineral gains during puberty, as up to $50 \%$ of the total adult bone mass is accrued at this age of life ${ }^{(3)}$. Vitamin D plays an integral role in bone mineralisation by promoting calcium absorption in the small intestine, and aids in maximising skeletal health from birth to death ${ }^{(4)}$. Vitamin D prevents rickets in children and osteomalacia in adults. Vitamin D deficiency during puberty can negatively impact calcium balance and availability for mineralisation of bone as well as aggravate age-related bone loss in adults ${ }^{(5)}$. Bones can become thin, brittle, soft or misshapen in subjects with vitamin D deficiency. Experts now define a safe circulating minimum level of 25 -hydroxyvitamin $D$ at $70-80 \mathrm{nmol} / \mathrm{l}^{(6)}$. This serum level and high levels of dietary intake of vitamin D have been associated with significantly reduced risk of chronic diseases, such as osteoporosis, CVD, diabetes and some cancers ${ }^{(7)}$.

It is hard to believe the prevalence of vitamin D deficiency in a tropical country such as Bangladesh, where sunlight is abundant almost year-round. However, recent studies have reported a high prevalence of vitamin D deficiency, low dietary intake of calcium $(<300 \mathrm{mg} / \mathrm{d})$, and deficiencies in protein, energy and other micronutritients in Bangladeshi women ${ }^{(8-12)}$. Due to malnutrition, short stature and low body weight, Bangladeshi women in low-income groups could be at risk for low bone mass, osteoporosis and fracture ${ }^{(13-15)}$. Bharadwaj et al.

Abbreviations: BMC, bone mineral content; BMD, bone mineral density; DEXA, dual-energy X-ray absorptiometry; MUAC, mid-upper-arm circumference; S-ALP, serum alkaline phosphatase activity; S-Ca, serum calcium; S-iPTH, serum intact parathyroid hormone; S-25OHD, serum 25-hydroxyvitamin D; S-P, serum phosphate.

* Corresponding author: Dr Christel Lamberg-Allardt, fax +358 9 19158475, email christel.lamberg-allardt@helsinki.fi 
indicated that South Asian women reach menopause at an earlier age than do Caucasian women, and osteopenia and osteoporosis may also occur at a younger age ${ }^{(16)}$. However, no data are available on the prevalence of osteoporosis and fracture in the population of Bangladesh.

The export-based garment industries in Bangladesh are dominated by female labour and have employed more the 1.5 million young women of low socio-economic standing. These young women typically work $14-16 \mathrm{~h} / \mathrm{d}$ in an overcrowded, congested and poorly ventilated sub-standard environment. Due to their homebound lifestyle, with very little or no outdoor activity, and their low dietary intake of calcium and vitamin D coupled with skin pigment and frequent use of sunscreen, female garment factory workers may be at great risk for low vitamin D status and low bone mass. Their low levels of serum 25-hydroxyvitamin D (S-25OHD) are associated with a rise in intact parathyroid hormone (S-iPTH), which may adversely affect on bone mass. However, the level of S-25OHD at which S-iPTH starts to rise in this group is unknown.

The present study was designed to evaluate vitamin D status and bone parameters by using dual-energy X-ray absorptiometry (DEXA) and to determine the influence of nutritional status on bone mass. We studied the subjects to determine whether there is a relationship between levels of S-25OHD and S-iPTH and bone mass at the hip and spine.

\section{Subjects and methods}

\section{Subjects}

The present study was conducted in an export-oriented garment factory located in an urban area belonging to Standard Group Bangladesh, which maintains a high-quality working environment for its workers. The garment factory is situated in Mirpur in the city of Dhaka in a modern from multistoreyed building with good working facilities. A total of 200 subjects aged 18-36 years were randomly selected from the garment factory. The subjects of the present study were mainly young women from low-income rural families who migrated to the city for a job at least 2 years earlier. They live in low-cost accommodation with no indoor supply of water, no sanitary latrines and densely packed sleeping arrangements because of their low income and other liabilities. They work from dawn to dust, $7 \mathrm{~d} /$ week, and use covered-up style dresses 'Shari or Salwar' but their faces and hands remain uncovered. The eligibility criteria to include the subjects in the present study was no history of serious medical conditions, no history of medication known to affect bone metabolism, no current pregnancies, no lactation within the previous 3 years, and lived in the city for at least 2 years. In our previous studies, we experienced difficulties in carrying out a study among low-income subjects with low education levels. Consequently, our first approach was to contact the Chief Medical Officer of the Standard Group, to explain the purpose of the study and to ask for their co-operation. We found him most co-operative. We contacted the subjects through the Chief Medical Officer and explained to them the objectives of the study in an understandable way, and asked for their written consent to participate. The medical assistant of the Standard Group and our two field assistants also involved themselves in motivating the subjects. The subjects received a lucrative compensation for their loss of one day's work, which greatly encouraged them to participate in the study. Using this approach, the response rate was over $90 \%$. In Bangladesh, women, particularly in low-income groups, are very much afraid of giving blood samples. Therefore, blood samples were collected first. On weekly working days, a small group of about ten subjects were brought in a minibus to the Centre for Nuclear Medicine and Ultrasound, Sir Salimullah Medical College, Mitford, Dhaka, where the background information, anthropometric and DEXA measurements were carried out sequentially. The time subjects spent outside daily was recorded. The study was approved by the ethics committee of the Faculty of Agriculture and Forestry, University of Helsinki. During the field study in Bangladesh, we also followed the ethical guidelines of the University of Dhaka.

\section{Laboratory measurements}

Fasting blood samples were collected between 08.30 and 10.00 hours through venepuncture using disposable syringes protected from sunlight. After clotting, the serum was separated by complete centrifuge of the blood sample. The serum was collected in tubes and preserved at $-20^{\circ} \mathrm{C}$. Finally, the serum sample was transported to Helsinki in a special type of container with dry ice and preserved in the freezing room of the Division of Nutrition, Department of Applied Chemistry and Microbiology, University of Helsinki at $-20^{\circ} \mathrm{C}$ until analysis.

S-25OHD was used to evaluate the vitamin D status. The S-25OHD concentration was determined by the enzyme-immunoassay method with kits from OCTEIA (IDS, Boldon, UK). The intra- and inter-assay $\mathrm{CV}$ were 5.4 and $7.0 \%$, respectively. The S-iPTH level was measured with a commercial two-site immunoenzymometric assay (OCTEIA) with $10-65 \mathrm{ng} / \mathrm{l}$ as reference range. Intra- and inter-assay CV for iPTH were 3.5 and $5.6 \%$, respectively. Serum levels of alkaline phosphatase activity (S-ALP), calcium (S-Ca), phosphate (S-P) and creatinine were measured with an automated KoneLab spectrophotometer (Thermo Clinical Labsystems Ltd, Espoo, Finland) using routine methods to obtain additional information about vitamin $\mathrm{D}$ status. The interand intra-assay $\mathrm{CV}$ for these analyses were less than $7.5 \%$. The laboratory analysis was carried out at the Department of Applied Chemistry and Microbiology. We defined vitamin D deficiency as $\mathrm{S}-25 \mathrm{OHD}$ levels $<25 \mathrm{nmol} / \mathrm{l}$ and the reference range was $25-120 \mathrm{nmol} / \mathrm{l}$ for adults. We defined secondary hyperparathyroidism as S-iPTH levels $>65 \mathrm{ng} / \mathrm{l}$. The abnormally high values of serum variables were not included for statistical analysis. The study was conducted from April to May 2004. In fact, no difference in sunshine during this period existed that could substantially affect vitamin D status.

\section{Bone mineral density measurements}

The measurements of bone mineral content (BMC) and bone mineral density (BMD) of the left femur region and lumbar spine L2-L4 vertebrae (in anterio-posterior projection) were made by a single trained X-ray technician using DEXA (Norland XR 36; Norland Corp., Fort Atkinson, WI, USA). The femoral region includes the femoral neck, 
trochanter and Ward's triangle. Calibration of the measurement was performed using a spine phantom, the inter-assay $\mathrm{CV}$ for the phantom was $0.45 \%$. Intra-assay CV were determined with duplicate measurements of ten subjects. CV for BMD in the left femur and lumbar vertebrae were 0.71 and $1.45 \%$, respectively.

\section{Other data}

A questionnaire was used to collect information on height, weight, age at menarche, length of living in the city, daily time spent outdoors, etc. As the study was carried out in a Muslim community of Bangladesh, we considered the acceptability of the anthropometric measurements to the subjects. We measured height, weight, biceps, triceps skinfolds, midupper-arm circumference (MUAC); head, waist and hip circumference, and found it difficult to measure the thickness of suprailiac and subscapular skinfolds as these measurements would have hurt their religious integrity. Standing height was measured with a wall-mounted scale to the nearest $0.5 \mathrm{~cm}$. Body weight was measured without shoes and with light clothing on a portable weighing scale to the nearest $0.5 \mathrm{~kg}$. We used the classifications of BMI (weight $(\mathrm{kg}) /$ height $\left(\mathrm{cm}^{2}\right)$ ) recommended by the $\mathrm{WHO}^{(17)}$. A Harpenden calliper was used to measure skinfold thickness, and a measuring tape was used for the measurements of MUAC, head, waist and hip circumference.

\section{Statistical analyses}

The statistical analysis was completed using SPSS version 12.0 (SPSS Inc., Chicago, IL, USA). Data are presented as means and standard deviations. Group comparison was made by the $t$ test. Correlation between variables was estimated by using Pearson's coefficient of correlation. The association between S-25OHD and S-iPTH concentrations was studied both by linear and non-linear regression models. The determinants of S-25OHD and S-iPTH concentrations were studied in the regression models. Age, BMI, S-25OHD, S-ALP, S-Ca and S-P were used in the regression models to study the determinants of S-iPTH concentration. The relationships of S-25OHD and S-iPTH with femoral and lumbar BMD were studied by the Mann-Whitney rank-sum test and ANCOVA. $P$ values $<0.05$ were considered significant.

\section{Results}

A summary of the descriptive and biochemical characteristics of the study population is given in Table 1. A high prevalence of short stature and low BMI was observed in the study, which emphasises the vulnerability of this group to malnutrition. About $90 \%$ of the subjects were originally from rural lowincome families and migrated to the city in search of a job.

Of note, more than $99 \%$ of the subjects studied had an $\mathrm{S}$-25OHD level below the lower limit of the desirable range of $75-125 \mathrm{nmol} / \mathrm{l}^{(18)}$. A S-25OHD level of $50 \mathrm{nmol} / 1$ or higher can be considered appropriate ${ }^{(19)}$. The mean S-25OHD level $(36 \cdot 7 \mathrm{nmol} / \mathrm{l})$ was below this safe lower reference limit. According to Lips's and Vieth's classification, vitamin D deficiency was mild (S-25OHD level $25-50 \mathrm{nmol} / \mathrm{l}$ ) in 141 $(70.5 \%)$ subjects, moderate (S-25OHD level $12 \cdot 5-24 \mathrm{nmol} / \mathrm{l})$
Table 1. Descriptive and biochemical characteristics of the study population ( $n$ 200)

(Mean values and standard deviations)

\begin{tabular}{|c|c|c|c|}
\hline & Mean & SD & Range \\
\hline Age (years) & $22 \cdot 6$ & $3 \cdot 7$ & $18-38$ \\
\hline Weight (kg) & $48 \cdot 6$ & $6 \cdot 8$ & $33-74$ \\
\hline Height $(\mathrm{cm})$ & $149 \cdot 8$ & $5 \cdot 0$ & $135-164$ \\
\hline BMI $\left(\mathrm{kg} / \mathrm{m}^{2}\right)$ & $21 \cdot 6$ & $2 \cdot 7$ & $15 \cdot 8-30 \cdot 4$ \\
\hline Bicep skinfold (mm) & 4.6 & 1.6 & $2 \cdot 1-14 \cdot 2$ \\
\hline Tricep skinfold (mm) & $11 \cdot 4$ & $3 \cdot 5$ & $4 \cdot 7-21 \cdot 2$ \\
\hline MUAC $(\mathrm{cm})$ & 24.5 & $2 \cdot 6$ & $15 \cdot 0-31 \cdot 0$ \\
\hline Waist circumference $(\mathrm{cm})$ & $72 \cdot 3$ & $6 \cdot 9$ & $57-95$ \\
\hline Hip circumference $(\mathrm{cm})$ & 89.5 & $6 \cdot 8$ & $71-107$ \\
\hline S-iPTH (ng/l) & $23 \cdot 1$ & $11 \cdot 4$ & $1 \cdot 8-67 \cdot 3$ \\
\hline $\mathrm{S}-25 \mathrm{OHD}(\mathrm{mmol} / \mathrm{l})$ & $36 \cdot 7$ & $11 \cdot 2$ & $11 \cdot 3-83 \cdot 5$ \\
\hline S-ALP (U/I) & $59 \cdot 7$ & $19 \cdot 4$ & $28-156$ \\
\hline $\mathrm{S}-\mathrm{Ca}(\mathrm{mmol} / \mathrm{l})$ & $2 \cdot 36$ & $0 \cdot 16$ & $1 \cdot 90-3 \cdot 40$ \\
\hline $\mathrm{S}-\mathrm{P}(\mathrm{mmol} / \mathrm{l})$ & 1.26 & 0.46 & $0.61-3.24$ \\
\hline Serum creatinine $(\mu \mathrm{mol} / \mathrm{l})$ & 76.49 & $14 \cdot 28$ & $43-160$ \\
\hline \multicolumn{4}{|c|}{$\operatorname{BMD}\left(\mathrm{g} / \mathrm{cm}^{2}\right)$ and BMC $(\mathrm{g})$ at different sites } \\
\hline Femoral neck $\left(\mathrm{g} / \mathrm{cm}^{2}\right)$ & 0.788 & 0.106 & $0.465-1.147$ \\
\hline Femoral neck $(\mathrm{g})$ & 3.375 & 0.535 & $1 \cdot 743-5 \cdot 289$ \\
\hline Trochanter $\left(\mathrm{g} / \mathrm{cm}^{2}\right)$ & 0.624 & 0.0893 & $0.346-0.924$ \\
\hline Trochanter (g) & $5 \cdot 863$ & $1 \cdot 189$ & $3.032-9.465$ \\
\hline Ward's triangle $\left(\mathrm{g} / \mathrm{cm}^{2}\right)$ & 0.645 & 0.118 & $0.297-1.042$ \\
\hline Femoral neck $T$-score & -1.883 & 0.908 & $-4.57-1.36$ \\
\hline Lumbar spine L2 (g/cm²) & 0.871 & 0.116 & $0.283-1.248$ \\
\hline Lumbar spine L2 (g) & $9 \cdot 617$ & 1.689 & $1 \cdot 898-15 \cdot 640$ \\
\hline Lumbar spine L3 $\left(\mathrm{g} / \mathrm{cm}^{2}\right)$ & 0.909 & $0 \cdot 123$ & $0.336-1.270$ \\
\hline Lumbar spine L3 (g) & $11 \cdot 161$ & 1.989 & $4 \cdot 473-18 \cdot 360$ \\
\hline Lumbar spine L4 $\left(\mathrm{g} / \mathrm{cm}^{2}\right)$ & 0.898 & 0.120 & $0.334-1.293$ \\
\hline Lumbar spine L4 (g) & 11.444 & $1 \cdot 848$ & $3 \cdot 485-16 \cdot 370$ \\
\hline $\begin{array}{l}\text { Lumbar spine } \\
\qquad 2-\mathrm{L} 4\left(\mathrm{~g} / \mathrm{cm}^{2}\right)\end{array}$ & 0.894 & 0.116 & $0.323-1.222$ \\
\hline Lumbar spine L2-L4 (g) & $32 \cdot 222$ & $5 \cdot 074$ & $9 \cdot 857-47 \cdot 750$ \\
\hline Lumbar spine $T$-score & -1.6444 & 0.784 & $-5 \cdot 19-2 \cdot 78$ \\
\hline
\end{tabular}

BMC, bone mineral content; BMD, bone mineral density; MUAC, mid-upper-arm circumference; S-ALP, serum alkaline phosphatase activity; S-Ca, serum calcium; S-iPTH, serum intact parathyroid hormone; S-25OHD, serum 25 -hydroxyvitamin D; S-P, serum phosphate.

in thirty $(15 \%)$ and severe (S-25OHD level $<12.5 \mathrm{nmol} / \mathrm{l})$ in one subject $(0.5 \%)^{(19,20)}$. Several cut-off points were used to describe the prevalence of vitamin D inadequacy in the study population (Fig. 1). Age and BMI did not correlate with S-25OHD $\left(r^{2} 0 \cdot 004\right.$ and 0.002, respectively), S-25OHD associated negatively with $\mathrm{S}$-iPTH and S-ALP concentrations ( $r-0.25, P \leq 0.001$ and $r-0.22, P \leq 0.05$, respectively). A negative association was observed between S-25OHD and SCa concentration $(r-0 \cdot 20, P \leq 0 \cdot 05)$ as well. None of the subjects had S-25OHD level above the normal range. One subject exhibited an abnormally high level of S-iPTH (450 ng/l) with vitamin insufficiency and one subject had secondary hyperparathyroidism (S-iPTH level $>65 \mathrm{ng} / \mathrm{l})$.

To study the determinants of S-iPTH concentration, the following variables were used in the regression models: age, BMI, S-25OHD, S-Ca and S-P concentrations. The model explains $19 \%$ of the variance in the S-iPTH concentration. S-25OHD, S-Ca and S-P associated negatively with the S-iPTH concentration, S-ALP associated positively with the S-iPTH concentration, and age also tended to do so. BMI did not associate with the S-iPTH concentration.

In the linear regression analysis, one unit increase in the S-25OHD concentration on the In scale decreased S-iPTH levels on the In scale by 0.298 units $(P=0.014)$. In addition 


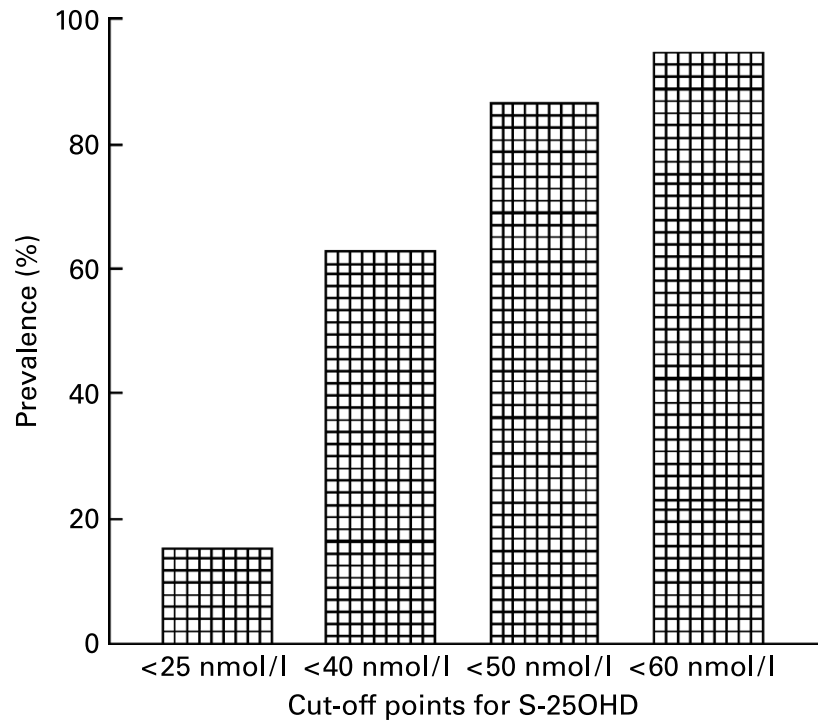

Fig. 1. Prevalence of vitamin $D$ inadequacy in subjects: the percentage of subjects with serum 25-hydroxyvitamin D (S-25OHD) concentrations below predefined cut-offs of $<25,<40,<50$ and $<60 \mathrm{nmol} / \mathrm{l}$.

to the linear model, a non-linear regression model was fitted between S-25OHD and S-iPTH concentrations (Fig. 2). Based on the relationship between S-25OHD and S-iPTH concentrations, the plateau for the S-iPTH concentration was reached at $21 \mathrm{ng} / \mathrm{l} \quad(21.4 \mathrm{ng} / \mathrm{l}=20.8 \mathrm{ng} / \mathrm{l}+186.3 \times$ $\exp (-0.150 \times 38 \mathrm{nmol} / \mathrm{l})]$. We observed that S-25OHD concentrations higher than about $38 \mathrm{nmol} / 1$ were required to keep S-iPTH concentrations low. Of the 200 females in the present study, $118(59 \%)$ showed S-25OHD concentration equal to or lower than $38 \mathrm{nmol} / \mathrm{l}$.

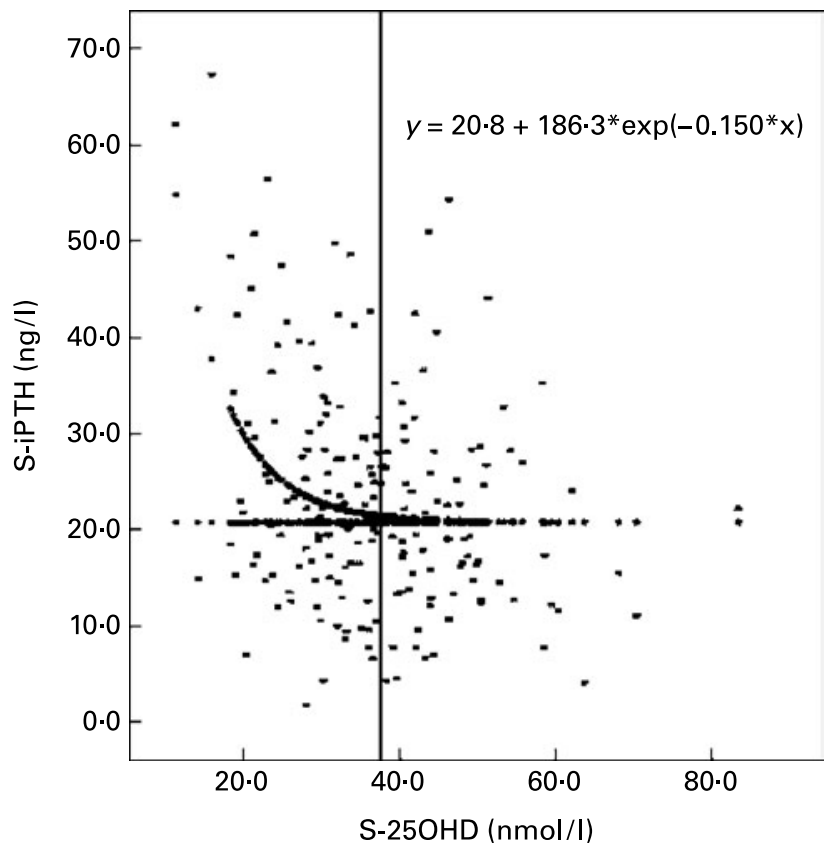

Fig. 2. Association between serum 25-hydroxyvitamin $D(S-25 O H D)$ and serum intact parathyroid hormone (S-iPTH) concentrations in a non-linear regression model.
BMD was overall low at all sites (Table 1). According to the WHO criteria, the mean $T$-scores of the femoral neck and lumbar spine of the subjects were within osteopenic range ${ }^{(21)}$ and the prevalence of osteopenia in the subjects was predominantly high $(>80 \%)$. Based on the $T$-scores of the left femur and lumbar spine, the prevalence of osteopenia $(T$-score $<-1 \cdot 0)$ was similar, but we observed a significant difference in the prevalence of osteoporosis (T-score $<-2.5)$ (Fig. 3). We observed that subjects with a $T$-score $<-2.5$ had a trend of lower body weight, waisthip circumference, MUAC and S-25OHD levels, and higher $\mathrm{S}$-iPTH and S-ALP levels. There was no difference in age in the subjects with $T$-scores $>-2.5$ and $<-2.5$. The biological characteristics of the study population, according to $T$-scores above and below 2.5 at the femoral neck and lumbar spine are shown in Table 2. A significantly lower lumbar spine BMD was observed in the subjects $(P<0 \cdot 05)$ with higher S-iPTH concentrations $(>21 \mathrm{ng} / \mathrm{l})$. In addition, we observed a trend of progressive increase in femoral neck and lumbar spine BMD (Table 3) with high S-25OHD concentrations $(>38 \mathrm{nmol} / \mathrm{l})$.

To study the influence of BMI values on bone parameters, we divided the subjects into three groups based on the WHO's recommended criteria of BMI for Asians ${ }^{(17)}$. The study subjects were categorised based on BMI values of $<18.5$ (group A), $18.5-22.9$ (group B) and $\geq 23$ (group C). In the present study, we observed the influence of BMI on bone parameters $(P<0.005)$; the values related to bone mass were significantly higher in group $\mathrm{C}$ than in group A for most of the bone parameters (Table 4). The mean $T$-scores both at the femoral neck and lumbar spine for all three groups were within the osteopenic range or closer to the osteoporotic range, although selected subjects were between 18 and 36 years of age.

\section{Discussion}

We have investigated the effect of exclusive indoor working lifestyle on vitamin D status and BMD parameters of premenopausal female garment factory workers. We observed in detail the association between S-25OHD, S-iPTH and bone mass in this population group. The investigation showed a

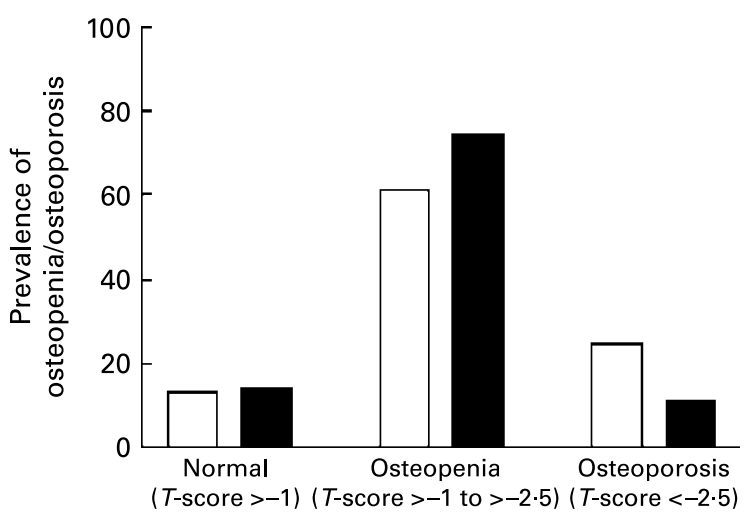

Fig. 3. Prevalence of osteopenia and osteoporosis in subjects: $T$-scores as defined by WHO (osteopenia $T$-score $<-1$; osteoporosis $T$-score $<-2.5$, sex- and race-controlled young adults). $\square, T$-score of the femoral neck; $\mathbf{\square}$, $T$-score of the lumbar spine. 
Table 2. Comparison of the physical and biochemical characteristics of the subjects with $T$-score values above and below -2.5 at femoral neck and lumbar spine

(Mean values and standard deviations)

\begin{tabular}{|c|c|c|c|c|c|c|c|c|c|c|}
\hline & \multicolumn{4}{|c|}{ Femoral neck $T$-score } & \multirow[b]{3}{*}{$P$ value } & \multicolumn{4}{|c|}{ Lumbar spine $T$-score } & \multirow[b]{3}{*}{$P$ value } \\
\hline & \multicolumn{2}{|c|}{$>-2 \cdot 5$} & \multicolumn{2}{|c|}{$<-2.5$} & & \multicolumn{2}{|c|}{$>-2.5$} & \multicolumn{2}{|c|}{$<-2.5$} & \\
\hline & Mean & SD & Mean & SD & & Mean & SD & Mean & SD & \\
\hline Cases & 150 & & 50 & & & 178 & & 22 & & \\
\hline Age (years) & 22.8 & 3.6 & $21 \cdot 8$ & 3.7 & 0.076 & $22 \cdot 7$ & 3.7 & $21 \cdot 1$ & 2.5 & 0.012 \\
\hline Weight (kg) & $49 \cdot 3$ & $7 \cdot 1$ & $46 \cdot 3$ & $5 \cdot 1$ & 0.003 & 48.9 & $6 \cdot 9$ & 46.5 & $5 \cdot 8$ & 0.095 \\
\hline Height (cm) & 149.9 & $5 \cdot 1$ & 149.7 & 4.8 & 0.875 & 149.9 & $5 \cdot 0$ & $149 \cdot 0$ & $5 \cdot 2$ & 0.441 \\
\hline $\mathrm{BMI}\left(\mathrm{kg} / \mathrm{m}^{2}\right)$ & $22 \cdot 0$ & $2 \cdot 8$ & 20.6 & 2.4 & 0.002 & $21 \cdot 7$ & $2 \cdot 7$ & 20.9 & $2 \cdot 8$ & 0.237 \\
\hline Bicep skinfold (mm) & 4.6 & 1.6 & 4.6 & 1.8 & 0.950 & 4.6 & 1.6 & 4.7 & 1.9 & 0.908 \\
\hline Tricep skinfold (mm) & 11.4 & 3.5 & 11.4 & 3.5 & 0.926 & 11.5 & 3.5 & $11 \cdot 1$ & 3.5 & 0.640 \\
\hline WC $(\mathrm{cm})$ & $72 \cdot 7$ & $7 \cdot 1$ & $71 \cdot 2$ & $6 \cdot 0$ & $0 \cdot 114$ & 72.5 & $7 \cdot 0$ & 70.5 & 5.4 & 0.125 \\
\hline $\mathrm{HC}(\mathrm{cm})$ & $90 \cdot 0$ & $7 \cdot 1$ & 87.9 & 5.9 & 0.040 & 89.7 & $7 \cdot 0$ & 87.5 & 5.5 & 0.091 \\
\hline MUAC $(\mathrm{cm})$ & 24.7 & $2 \cdot 6$. & $24 \cdot 8$ & $2 \cdot 4$ & 0.042 & $24 \cdot 7$ & 2.5 & 23.3 & 2.7 & 0.022 \\
\hline S-25OHD (nmol/l) & 37.6 & 11.4 & $34 \cdot 3$ & $10 \cdot 2$ & 0.067 & $36 \cdot 6$ & $10 \cdot 6$ & $35 \cdot 7$ & $10 \cdot 9$ & 0.404 \\
\hline S-iPTH (ng/l) & $23 \cdot 2$ & 11.3 & $24 \cdot 8$ & 11.9 & 0.788 & $22 \cdot 7$ & $10 \cdot 9$ & $26 \cdot 0$ & 14.9 & 0.215 \\
\hline S-ALP (U/l) & $58 \cdot 7$ & $19 \cdot 3$ & 62.5 & $19 \cdot 7$ & 0.247 & 58.5 & $18 \cdot 2$ & 69.3 & 26.5 & 0.016 \\
\hline $\mathrm{S}-\mathrm{Ca}(\mathrm{mmol} / \mathrm{l})$ & $2 \cdot 36$ & 0.15 & $2 \cdot 35$ & $0 \cdot 18$ & 0.802 & 2.35 & 0.15 & $2 \cdot 41$ & 0.23 & 0.151 \\
\hline S-P $(\mathrm{mmol} / \mathrm{l})$ & 1.23 & 0.43 & 1.33 & 0.57 & 0.260 & 1.25 & 0.47 & 1.28 & 0.45 & 0.817 \\
\hline Serum creatinine $(\mu \mathrm{mol} / \mathrm{l})$ & $77 \cdot 4$ & 14.8 & 73.5 & $12 \cdot 2$ & 0.064 & $77 \cdot 7$ & 14.4 & 71.7 & $12 \cdot 4$ & 0.071 \\
\hline
\end{tabular}

HC, hip circumference; MUAC, mid-upper-arm circumference; S-ALP, serum alkaline phosphatase activity; S-Ca, serum calcium; S-iPTH, serum intact parathyroid hormone; S-25OHD, serum 25-hydroxyvitamin D; S-P, serum phosphate; WC, waist circumference.

Table 3. Differences in femoral neck and lumbar spine bone mineral parameters, and physical and biochemical variables in the subjects divided into two categories according to serum 25-hydroxyvitamin D (S-25OHD) concentration $(\leq 38$ or $>38 \mathrm{nmol} / \mathrm{l})$

(Mean values and standard deviations)

\begin{tabular}{|c|c|c|c|c|c|}
\hline & \multicolumn{4}{|c|}{$\mathrm{S}-25 \mathrm{OHD}(\mathrm{nmol} / \mathrm{l})$} & \multirow[b]{3}{*}{$P$ value } \\
\hline & \multicolumn{2}{|c|}{$\leq 38(n 118)$} & \multicolumn{2}{|c|}{$>38(n 82)$} & \\
\hline & Mean & SD & Mean & SD & \\
\hline \multicolumn{6}{|l|}{$\mathrm{BMD}\left(\mathrm{g} / \mathrm{cm}^{2}\right)$ and BMC $(\mathrm{g})$} \\
\hline Femoral neck $\left(\mathrm{g} / \mathrm{cm}^{2}\right)$ & 0.776 & $0 \cdot 108$ & 0.804 & 0.102 & 0.070 \\
\hline Femoral neck (g) & 3.329 & 0.534 & 3.441 & 0.533 & 0.149 \\
\hline Femoral neck $T$-score & -1.965 & 0.944 & -1.764 & 0.844 & 0.126 \\
\hline Trochanter $\left(\mathrm{g} / \mathrm{cm}^{2}\right)$ & 0.618 & 0.090 & 0.633 & 0.087 & 0.237 \\
\hline Trochanter (g) & $5 \cdot 792$ & 1.209 & 5.965 & $1 \cdot 158$ & 0.313 \\
\hline Ward's triangle $\left(\mathrm{g} / \mathrm{cm}^{2}\right)$ & 0.638 & 0.118 & 0.656 & 0.117 & 0.275 \\
\hline Lumbar spine L2 $\left(\mathrm{g} / \mathrm{cm}^{2}\right)$ & 0.859 & 0.111 & 0.890 & 0.120 & 0.063 \\
\hline Lumbar spine L2 (g) & 9.55 & 1.611 & 9.990 & 1.737 & 0.009 \\
\hline Lumbar spine L3 $\left(\mathrm{g} / \mathrm{cm}^{2}\right)$ & 0.895 & 0.118 & 0.929 & 0.128 & 0.055 \\
\hline Lumbar spine L3 (g) & 10.906 & 1.905 & 11.524 & 2.062 & 0.031 \\
\hline Lumbar spine L4 $\left(\mathrm{g} / \mathrm{cm}^{2}\right)$ & 0.884 & 0.111 & 0.918 & 0.129 & 0.050 \\
\hline Lumbar spine L4 (g) & 11.264 & 1.734 & 11.700 & 1.981 & 0.101 \\
\hline Lumbar spine L2-L4 $\left(\mathrm{g} / \mathrm{cm}^{2}\right)$ & 0.880 & 0.110 & 0.913 & 0.122 & 0.050 \\
\hline Lumbar spine L2-L4 (g) & 31.526 & 4.814 & 33.215 & $5 \cdot 296$ & 0.020 \\
\hline Lumbar spine $T$-score & -1.708 & 0.796 & -1.551 & 0.763 & 0.165 \\
\hline \multicolumn{6}{|c|}{ Physical and biochemical characterics } \\
\hline Age (years) & 22.5 & 3.8 & $22 \cdot 6$ & 3.47 & 0.988 \\
\hline BMI $\left(\mathrm{kg} / \mathrm{m}^{2}\right)$ & 21.4 & 2.7 & 21.9 & $2 \cdot 8$ & 0.364 \\
\hline Bicep skinfold (mm) & $4 \cdot 6$ & 1.7 & 4.6 & 1.6 & 0.935 \\
\hline Tricep skinfold (mm) & $11 \cdot 3$ & 3.3 & 11.6 & 3.8 & 0.526 \\
\hline Waist circumference $(\mathrm{cm})$ & $72 \cdot 1$ & 6.9 & $72 \cdot 6$ & $6 \cdot 9$ & 0.622 \\
\hline S-iPTH (ng/l) & 24.7 & $12 \cdot 0$ & $20 \cdot 8$ & $10 \cdot 1$ & 0.014 \\
\hline $\mathrm{S}-25 \mathrm{OHD}(\mathrm{nmol} / \mathrm{l})$ & 29.3 & $6 \cdot 0$ & $47 \cdot 33$ & $8 \cdot 1$ & 0.000 \\
\hline $\mathrm{S}-\mathrm{Ca}(\mathrm{mmol} / \mathrm{l})$ & 2.34 & 0.15 & 2.39 & 0.17 & 0.039 \\
\hline $\mathrm{S}-\mathrm{P}(\mathrm{mmol} / \mathrm{l})$ & 1.32 & 0.57 & $1 \cdot 16$ & 0.20 & 0.018 \\
\hline S-ALP (U/I) & $61 \cdot 7$ & $20 \cdot 2$ & $56 \cdot 7$ & 17.9 & 0.069 \\
\hline Serum creatinine $(\mu \mathrm{mol} / \mathrm{l})$ & 75.9 & $13 \cdot 1$ & $77 \cdot 3$ & $15 \cdot 8$ & 0.527 \\
\hline
\end{tabular}

BMC, bone mineral content; BMD, bone mineral density; S-ALP, serum alkaline phosphatase activity; S-Ca, serum calcium; S-iPTH, serum intact parathyroid hormone; S-P, serum phosphate. 
Table 4. Bone variables at different sites in three groups, categorised based on BMI values for Asian people

(Mean values and standard deviations)

\begin{tabular}{|c|c|c|c|c|c|c|c|c|}
\hline \multirow{2}{*}{$\begin{array}{l}\mathrm{BMD}\left(\mathrm{g} / \mathrm{cm}^{2}\right) \text { and } \mathrm{BMC} \\
\text { (g) at different sites }\end{array}$} & \multicolumn{2}{|c|}{$\begin{array}{c}\text { Group A }(n 24) \\
\left(\mathrm{BMI}<18.5 \mathrm{~kg} / \mathrm{m}^{2}\right)\end{array}$} & \multicolumn{2}{|c|}{$\begin{array}{c}\text { Group B }(n 110)(\mathrm{BMI} \\
\left.18.5-22.9 \mathrm{~kg} / \mathrm{m}^{2}\right)\end{array}$} & \multicolumn{2}{|c|}{$\begin{array}{c}\text { Group C }(n 64) \\
\left(\mathrm{BMI} \geq 23 \mathrm{~kg} / \mathrm{m}^{2}\right)\end{array}$} & \multirow[b]{2}{*}{$P$ value ${ }^{*}$} & \multirow[b]{2}{*}{$P$ value } \\
\hline & Mean & SD & Mean & SD & Mean & SD & & \\
\hline Femoral neck ( $\left.\mathrm{g} / \mathrm{cm}^{2}\right)$ & 0.735 & 0.128 & 0.785 & 0.0985 & 0.815 & 0.104 & 0.102 & 0.005 \\
\hline Femoral neck (g) & $3 \cdot 204$ & 0.601 & $3 \cdot 345$ & 0.492 & 3.495 & 0.569 & $0 \cdot 724$ & 0.071 \\
\hline Femoral neck $T$-score & $-2 \cdot 340$ & 1.065 & -1.896 & 0.869 & -1.675 & 0.867 & 0.086 & 0.006 \\
\hline Trochanter $\left(\mathrm{g} / \mathrm{cm}^{2}\right)$ & 0.554 & 0.080 & 0.681 & 0.605 & 0.649 & 0.087 & 0.651 & 1.000 \\
\hline Ward's triangle $\left(\mathrm{g} / \mathrm{cm}^{2}\right)$ & 0.577 & 0.105 & 0.643 & 0.114 & 0.676 & 0.119 & 0.039 & 0.001 \\
\hline Lumbar spine L2 $\left(\mathrm{g} / \mathrm{cm}^{2}\right)$ & 0.802 & 0.148 & 0.856 & 0.094 & 0.925 & 0.117 & 0.093 & 0.000 \\
\hline Lumbar spine L2 (g) & 8.741 & $1 \cdot 861$ & $9 \cdot 337$ & 1.365 & $10 \cdot 419$ & 1.854 & 0.299 & 0.000 \\
\hline Lumbar spine L3 $\left(\mathrm{g} / \mathrm{cm}^{2}\right)$ & 0.839 & 0.139 & 0.893 & 0.108 & 0.908 & 0.123 & 0.124 & 0.000 \\
\hline Lumbar spine L3 (g) & $10 \cdot 233$ & $1 \cdot 785$ & $10 \cdot 857$ & 1.759 & $12 \cdot 038$ & $2 \cdot 173$ & 0.442 & 0.000 \\
\hline Lumbar spine L4 ( $\left.\mathrm{g} / \mathrm{cm}^{2}\right)$ & 0.833 & $0 \cdot 141$ & 0.882 & 0.105 & 0.951 & 0.118 & 0.187 & 0.000 \\
\hline Lumbar spine L4 (g) & $10 \cdot 714$ & 2.095 & $11 \cdot 127$ & 1.603 & $12 \cdot 272$ & 1.906 & 0.906 & 0.000 \\
\hline Lumbar spine L2-L4 (g/cm²) & 0.826 & 0.140 & 0.878 & 0.099 & 0.946 & 0.115 & 0.113 & 0.000 \\
\hline Lumbar spine $T$-score & -1.852 & $1 \cdot 304$ & -1.764 & 0.621 & $-1 \cdot 360$ & 0.725 & 1.000 & 0.024 \\
\hline
\end{tabular}

BMC, bone mineral content; BMD, bone mineral density.

* Group A v. group B.

† Group A v. group C.

high prevalence $(86 \%)$ of hypovitaminosis D (S-25OHD $<50$ $\mathrm{nmol} / \mathrm{l})$ in the study subjects, $16 \%$ of whom were found to have vitamin $\mathrm{D}$ deficiency $(\mathrm{S}-25 \mathrm{OHD}<25 \mathrm{nmol} / \mathrm{l})$. Based on the association between S-25OHD and S-iPTH concentrations, however, the situation was also critical: about $60 \%$ of the subjects showed insufficient vitamin D status.

In the present study, we noted that the subjects had a regular exposure to sunshine $(5-15 \mathrm{~min} / \mathrm{d})$, only in the very early morning on their way from home to their working place. It is a popular perception that being outdoors in the summer for $10-15 \mathrm{~min}$, two to three times in a week, is sufficient for effective vitamin D production in the $\operatorname{skin}^{(4)}$. However, the present study indicated the exposure to sunshine may be not effective enough for synthesis of vitamin D in the skin. The possible reasons could be low intensity of the sun in the morning or the shaded sunshine of an overcast sky, or shadows of tall buildings and trees, upright position of the subjects, the high pollution in the air, covered-up-style dresses as well as their dark skin which necessitate the need for prolonged exposure for adequate synthesis of vitamin $\mathrm{D}$ in the skin. In addition, we observed that nearly $90 \%$ of the female garment workers use sunscreen on their face and hands, which are generally exposed to sunlight. Despite the abundant sunlight, previous studies have also reported a high prevalence of vitamin D deficiency in South Asian countries $^{(13,22-26)}$. In fact, a comparison of the present findings on serum vitamin $\mathrm{D}$ data with other studies may not be entirely appropriate as the studies were conducted in different seasons, with different subjects groups and using different assays. We had no control group in the present study to compare the findings. However, in line with earlier findings, the present study also indicated an alarmingly high prevalence of hypovitaminosis D in Bangladeshi women ${ }^{(9-12)}$.

Vitamin D deficiency may cause secondary hyperparathyroidism and low BMD in post-menopausal women ${ }^{(27,28)}$. The present findings in young women do not agree with it and comply with the report that low S-25OHD does not always lead to an increase in the level of S-iPTH ${ }^{(29)}$. In the present study, one in 200 participants had hyperparathyroidism (S-iPTH $>65 \mathrm{ng} / \mathrm{l})$, which fails to explain why S-iPTH was increased in subjects with low S-25OHD concentrations.

The negative relationship between S-25OHD and S-iPTH has more often been used to establish the appropriate S-25OHD level. Substantial studies found that S-25OHD concentrations from about 30 to $125 \mathrm{nmol} / 1$ are required to maintain a normal S-iPTH level ${ }^{(18,29-31)}$. In the present study, we observed that S-iPTH began to rise when S-25OHD was lower than $38 \mathrm{nmol} / \mathrm{l}$. In the long run, S-25OHD concentrations lower than $38 \mathrm{nmol} / 1$ may adversely affect the BMD of the subjects. The inverse relationship between S-25OHD and $\mathrm{S}-\mathrm{iPTH}$ in the present subjects confirms hypovitaminosis $\mathrm{D}$ and its ultimate effects, such as low BMD. In fact, there is no universally accepted optimal range or cut-off value for S-25OHD available to define vitamin D deficiency or insufficiency. Secondly, the demarcation line between vitamin D sufficiency and insufficiency is not clearly defined. A recent report mentioned a reference range of $\mathrm{S}-25 \mathrm{OHD}$ $(135-225 \mathrm{nmol} / \mathrm{l})$ to indicate vitamin $\mathrm{D}$ sufficiency in the normal subjects of sunny countries ${ }^{(18)}$. Interestingly, no subject was found with an S-25OHD level above even the lower reference limit of these criteria.

Hypovitaninosis D is a common risk factor for increased bone remodelling and low bone mass ${ }^{(20)}$.

Subclinical vitamin D deficiency is considered to be a risk factor for osteoporosis and fractures ${ }^{(32)}$. In the present study, we observed a trend of progressive increase in femoral neck and lumbar spine BMD with high S-25OHD concentrations $(>38 \mathrm{nmol} / \mathrm{l})$. In addition, S-25OHD showed a very significant and positive $(P<0.001)$ influence on the BMD of Trochanter and Ward's triangle. Different investigators showed the relationship between S-25OHD and BMD at different skeletal sites ${ }^{(25,33-36)}$. Our explanation for this discrepancy in the association between skeletal site BMD and S-25OHD could be linked to differences in the sample size, the criteria for 
sample selection, ethnicity, country of origin and the dietary intake of calcium and vitamin D. Secondly, the correlation observed by different authors between S-25OHD and BMD at different degrees and skeletal sites could also support the fact that S-25OHD is one of the important factors that affect BMD. However, the present data showed the relationship between S-25OHD and BMD at two sites, and emphasised the effect of S-25OHD on BMD. This indicates that subclinical vitamin $\mathrm{D}$ deficiency in these subjects could be responsible for low BMD.

The association of BMI and weight to BMD and BMC is well documented. In the present study, we studied bone parameters in relation to the nutritional status of the subjects and observed that nutritional status (weight, BMI) is an important determinant of bone health. In the present investigation, BMI value and weight were found to influence significantly $(P<0.005)$ all of the bone parameters studied. We observed a significantly increasing trend in BMD and BMC values at all skeletal sites with increasing BMI (Table 4). The prevalence of $T$-scores $<-2.5$ was predominantly high in the subjects with low BMI. About $13 \%$ of the subjects were found with $\mathrm{BMI}<18 \cdot 5$, indicating their chronic energy deficiency. They were all at risk for fracture with $T$-scores far below the osteoporotic range.

No adequate data exist concerning low S-25OHD levels and bone health in premenopausal women. Data have shown that Asian women have lower BMD than Caucasian women ${ }^{(37-39)}$. In the present subjects, overall BMD at all sites was lower (Table 1) than in other Asian, European and American subjects $^{(40-42)}$. We observed a similarity in the BMD profile of the present subjects to the bone status of Indian women from low-income families and hospital staff ${ }^{(13,25)}$. Vietnamese females of similar height showed no difference in BMD at the femoral neck ${ }^{(37)}$. The present subjects were a homogeneous group because they were working in a similar occupational setting, were developmentally similar in terms of skeletal integration and because they came from low-income families. Due to the narrow age range, we found no influence of age on the BMD and BMC of the subjects.

Reports indicated that due to low bone mass, early menopause and other underlying causes, osteoporotic fractures occur 10-20 years earlier among the South Asians than among western Caucasians ${ }^{(13,43)}$. Studies have indicated that the intake of calcium in Bangladeshi women is very low $(<300 \mathrm{mg} / \mathrm{d})^{(8,11)}$. Low calcium intake, coupled with long periods of elevated calcium requirements as well as high prevalence of vitamin D insufficiency and low peak bone mass could be the underlying causes of the present status of BMD in the subjects of the present study. Low peak bone mass could lead to a high risk of osteoporosis in adult life.

\section{Conclusion}

The present investigation provides a database on BMD in female garment workers of Bangladesh. The results indicate a high frequency of S-25OHD insufficiency/deficiency and a high risk of low bone mass which could be related with osteomalacia or osteoporosis as DEXA measurements cannot distinctively differentiate between these two. The study also provides a negative influence of undernutrition on bone mass. Due to the similar lifestyle, occupation, social background, living and working environment shared by more than 1.5 million female garment workers of Bangladesh, this situation could be a serious concern. Therefore, both health professional and health policy makers should pay attention quickly to this 'silent epidemic' and take active measures to educate young Bangladeshi women about the importance of vitamin D and bone health. Refraining from the use of sunscreen, regularly spending $10-15$ min outdoors in the sunshine (especially during lunch time), adequate calcium intake, proper nutrition and exercise are strongly recommended to combat both primary and secondary risk factors for low BMD in this population at risk. The results suggest that a clinical trial to improve vitamin D and BMD status and to minimise osteoporotic risk is essential in this population group in Bangladesh.

\section{Acknowledgements}

The study was supported by the research grants of the Development Fund of the Academy of Finland. The authors are highly grateful to officials of the directory board and Dr F. A. Arif Chief Medical Officer of the Standard Group for their tireless help during the course of the study. The authors sincerely wish to thank the 200 volunteer subjects.

M. Z. I. and C. L.-A. designed the study and secured funding. M. Z. I. was the principal investigator of the study, managed data collection, and was involved in data entry, statistical analysis and manuscript write-up. C. L.-A. checked the manuscript thoroughly and approved the final version. V. K. participated in laboratory analysis of serum samples. A. N. and M. L. participated in statistical analysis. A. A. S., M. A., A. H. J., K. J. and H. U. K. contributed to data collection and administration of the field study. C. L.-A. and M. Z. I are guarantors of the study. None of the contributing authors had any financial or personal interests in any of the bodies sponsoring this research.

\section{References}

1. Heaney RP, Abrams S, Dawson-Hughes B, Looker A, Marcus R, Matkovic V \& Weaver C (2000) Peak bone mass. Osteoporos Int 11, 985-1009.

2. Cooper C, Eriksson JG, Forsen T, Osmond C, Tuomilehto J \& Barker D (2001) Maternal height, childhood growth and risk of hip fracture in later life: a longitudinal study. Osteoporos Int 12, 623-639.

3. Gordon CL, Halton JM, Atkinson SA \& Webber CE (1991) The contributions of growth and puberty to peak bone mass. Growth Dev Aging 55, 257-262.

4. Holick MF (2002) Vitamin D: the underappreciated D-lightful hormone that is important for skeletal and cellular health. Curr Opin Endocrinol Diabetes 9, 87-98.

5. Chapuy MC, Arlot ME, Duboeuf F, Brun J, Crouzet B, Arnaud S, Delmas PD \& Meunier PJ (1992) Vitamin $D_{3}$ and calcium to prevent hip fractures in elderly women. N Eng J Med 327, $1637-1642$.

6. Vieth R (2005) The role D in the prevention of osteoporosis. Ann Med 37, 278-285.

7. Holick MF (2005) Vitamin D: important for the prevention of osteoporosis, cardiovascular heart disease, type 1 diabetes, autoimmune diseases, and some cancers. South Med J 98, $1024-1027$. 
8. Jahan K \& Hossain M (1998) Nature and Extent of Malnutrition in Bangladesh. Bangladesh National Nutrition Survey 1995-1996, Dhaka, Bangladesh. Dhaka: Institute of Nutrition and Food Science, University of Dhaka.

9. Islam MZ (2000) Vitamin D, Iron, Calcium and Overall Nutritional Status in Premenopausal Women in Two Regions of Bangladesh. Helsinki: Yliopistopaino.

10. Islam MZ, Lamberg-Allardt C, Kärkkainen M, Outila T, Salamatullah Q \& Shamim AA (2002) Vitamin D deficiency: a concern in Bangladeshi women of two socio-economic groups. Eur $J$ Clin Nutr 56, 51-56.

11. Islam MZ, Lamberg-Allardt $C$, Kärkkäinen $M$ \& Ali SMK (2002) Dietary calcium intake in premenopausal Bangladeshi women: do socio-economic or physiological factors play a role? Eur J Clin Nutr 57, 674-680.

12. Islam MZ, Akhtaruzzaman M \& Lamberg-Allardt C (2006) Hypovitaminosis D is common in both veiled and nonveiled Bangladeshi women. Asia Pacific J Clin Nutr 15, 81-87.

13. Shatrugna V, Kulkarni B, Kumar PA, Rani KU \& Balakrishna N (2005) Bone status of Indian women from low-income group and its relationship to the nutritional status. Osteoporos Int 16, $1827-1835$

14. Felson DT, Zhang YQ, Hannan MT \& Anderson JJ (1993) Effects of weight and body mass index on bone mineral density in men and women: the Framingham study. J Bone Miner Res 8, 567-573.

15. Stevenson JC, Lees B, Devenport M, Cust MP \& Ganger KF (1989) Determinants of bone density in normal women: risk factors for osteoporosis? Br Med J 298, 924-928.

16. Bharadwaj JA, Kendurkar SM \& Vaidya PR (1983) Age and symptomatology of menopause in Indian women. J Postgrad Med 29, 218-222.

17. World Health Organization, International Association for the study of Obesity, International Obesity Task Force (2000) The Asia-Pacific Perspective: Redefining Obesity and its Treatment. Sydney: Health Communications.

18. Grant WB \& Holick M (2005) Benefits and requirements of vitamin D for optimal health: a review. Altern Med Rev 10, 94-111.

19. Vieth R (1999) Vitamin D supplementation, 25-hydroxyvitamin D concentrations and safety. Am J Clin Nutr 69, 842-856.

20. Lips P (2004) Which circulating level of 25-hydroxyvitamin D is appropriate? J Biochem Mol Biol 89/90, 611-614.

21. World Health Organization (1994) Assessment of Fracture Risk and Its Application to Screening for Postmenopausal Osteoporosis, Technical Report Series no. 843. Geneva: WHO.

22. Atiq M, Suria A, Nizami SQ \& Ahmed I (1998) Maternal vitamin D deficiency in Pakistan. Acta Obstet Gynecol Scand 77, 970-973.

23. Goswami R, Gupta N, Goswami D, Marwaha RK, Tandon N \& Koahupillai N (2000) Prevalence and significance of low 25hydroxyvitamin D concentrations in healthy subjects in Delhi. Am J Clin Nutr 72, 472-475.

24. Tandon N, Marwaha RK, Kalra S, Gupta N, Dudha A \& Kochupillai N (2003) Bone mineral parameters in healthy young Indian adults with optimal vitamin D availability. Int Med J India 16, 298-302.

25. Arya V, Bhambri R, Godbole MM \& Mithal A (2004) Vitamin $\mathrm{D}$ status and its relationship with bone mineral density in healthy Asian Indians. Osteoporos Int 15, 56-61.

26. Herm FB, Killguss H \& Stewart AG (2005) Osteomalacia in Hazara District, Pakistan. Trop Doct 35, 8-10.

27. Serhan E \& Holland MR (2002) Relationship of hypovitaminosis D and secondary hyperparathyroidism with bone mineral density among UK resident Indo-Asians. Ann Rheum Dis 61 , 456-458.

28. Sakuma M, Endo N, Oinuma T, Hayami T, Endo E, Yazawa T, Watanabe K \& Watanabe S (2006) Vitamin D and intact PTH status in patients with hip fracture. Osteoporos Int 17, $1608-1614$.

29. Chapuy MC, Preziosi P, Maamer M, Arnaud S, Galan P, Hercberg S \& Meunier PJ (1997) Prevalence of vitamin D insufficiency in an adult normal population. Osteoporos Int $\mathbf{7}$, 439-443.

30. Kinuamy HK, Gallagher JC, Rafferty KA \& Balhorn KE (1998) Dietary calcium and vitamin D intake in elderly women: effect on serum parathyroid hormone and vitamin D metabolites. Am J Clin Nutr 67, 342-348.

31. Lamberg-Allardt C, Outila TA, Kärkkäinen MUM, Rita HJ \& Valsta L (2001) Vitamin D deficiency and bone in healthy adults in Finland - could this be a concern in other parts of Europe. J Bone Miner Res 16, 2066-2073.

32. Lips P, Duong T, Oleksik A, Black D, Cummings S, Cox D \& Nickelsen T (2001) A global study of vitamin D status and parathyroid function in postmenopausal women with osteoporosis: baseline data from the Multiple Outcomes of Reloxifene Evaluation clinical trial. J Clin Endocrinol Metab 86, 1212-1221.

33. Scharla SH, Scheidt-Nave C, Leidig G, Woitge H, Wuster C, Seibel MJ \& Ziegler R (1996) Lower serum 25-hydroxyvitamin $\mathrm{D}$ is associated with increased bone resorption markers and lower bone density at the proximal femur in normal females: a population-based study. Exp Clin Endocrinol Diabet 104, 289-292.

34. Fradinger EE \& Zanchetta JR (2001) Vitamin D and bone mineral density in ambulatory women living in Buenos Aires, Argentina. Osteoporos Int 12, 24-27.

35. Malavolta N, Pratelli L, Frigato M, Mule R, Mascia ML \& Gnudi S (2005) The relationship of vitamin D status to bone mineral density in an Italian population of postmenopausal women. Osteoporos Int 16, 1691-1697.

36. Viljakainen HT, Natri AM, Kärkkäinen M, Huttunen MM, Palssa A, Jakobsen J, Cashman KD, Molgaard C \& LambergAllardt C (2006) A positive dose-response effect of vitamin D supplementation on site-specific bone mineral augmentation in adolescent girls - a double-blinded randomized placebo-controlled one year intervention. J Bone Miner Res 21, 836-844.

37. Marquez MA, Melton LJ, Muhs JM, Crowson CS, Tosomeen A, O'Connor MK, O'Fallon WM \& Riggs BL (2001) Bone density in an immigrant population from Southeast Asia. Osteoporos Int 12, 595-604.

38. Wu XP, Liao EY, Huang G, Dai RC \& Zhang H (2003) A comparison study of the reference curves of bone mineral density at different skeletal sites in native Chinese, Japanese and American caucasian women. Calcif Tissue Int 73, 122-132.

39. Mehta G, Taylor P, Petley G, Dennison E, Cooper C \& WalkerBone K (2004) Bone mineral status in immigrant Indo-Asian women. $Q J$ Med 97, 95-99.

40. Sigurdsson G, Franzson L, Steingrimsdottir L \& Sigvaldason H (2000) The association between parathyroid hormone, vitamin $\mathrm{D}$ and bone mineral density in 70-year-old Icelandic women. Osteoporos Int 11, 1031-1035.

41. Patel R, Collins D, Bullock S, Swaminathan R, Blake GM \& Fogelman I (2001) The effect of season and vitamin D supplementation on bone mineral density in healthy women: a double-masked crossover study. Osteoporos Int 12, 319-325.

42. Chee WS, Suriah AR, Chan SP, Zaitun Y \& Chan YM (2003) The effect of milk supplementation on bone mineral density in postmenopausal Chinese women in Malaysia. Osteoporos Int 14, 828-834.

43. Alekel DL, Mortillaro E, Hussain EA, West B, Ahmed N, Peterson CT, Werner RK, Arjmandi BH \& Kukreja SC (1999) Lifestyle and biologic contributors to proximal femur bone mineral density and hip axis length in two distinct ethnic groups of premenopausal women. Osteoporos Int 9, 327-338. 